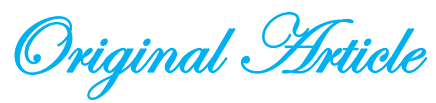

\title{
Possibility of Xanthine Oxidase and Malondialdehyde as a marker for Myocardial Infarction \\ Abdelhamid $\mathrm{MA}^{1}$, Salim $\mathrm{BI}^{2}$ and Abdelsalam $\mathrm{KA}^{3}$
}

\begin{abstract}
Background: the serum markers of myocardial injury are used to help in establishing the diagnosis of myocardial infarction.

Objective: to measure the levels of xanthine oxidase activity and malondialdehyde in myocardial infarction patients.

Methods: 100 patients with myocardial infarction and 50 healthy persons were included in this study. Xanthine oxidase activity assayed according to the method described by bergmeyer, h.u. while malondialdehyde (MDA) estimation was carried by thiobarbituric acid (TBA) based colorimetric method.
\end{abstract}

Results: significant increasing levels of xanthine oxidase activity and malondialdehyde were found in the blood of the patients with myocardial infarction when compared to healthy persons.

Conclusions: we propose the measurement of the blood levels of xanthine oxidase as a marker of myocardial infarction.

Keywords: thiobarbituric, aspartate amino-transferase, creatine kinase, troponin.

$\mathrm{M}$ yocardial ischemia results from the reduction of coronary flow to such an extent that supply of oxygen to the myocardium does not meet the oxygen demand of myocardial tissue. When this ischemia is prolonged and irreversible then myocardial cell death and necrosis occurs which is defined as myocardial infarction (MI). ECG is the most widely used method for the diagnosis of myocardial infarction, but many times ECG shows inconclusive pattern ${ }^{1}$. Estimation of serum biochemical markers of myocardial injury arises to confirm the diagnosis of myocardial injury.

The older markers like aspartate aminotransferase, creatine kinase, lactate dehydrogenase etc. lost their utility due to lack of specificity and limited sensitivities ${ }^{2}$. However, among the currently available markers the troponin test appears to be the most promising as far as its sensitivity, specificity, turnaround time and cost is concerned. Nevertheless, there are reports to show that abnormal levels of troponin are

1. Department of Biochemistry, U of K, Sudan

2. Department of Laboratory, Sudanese Armed Forces Hospital - Omdurman.

3. Faculty of Medical Laboratory Sciences -OIU. found in various conditions which are not related to acute coronary diseases ${ }^{2,}{ }^{3}$. It is clear from the foregoing review that none of the markers available so far meet all the criteria required for an ideal biochemical marker of myocardial injury.

Oxygen free radical generation has been shown to be an important mechanism of cellular injury in ischemic myocardium ${ }^{4}$. Several mechanisms have been proposed to be involved in the generation of oxygen free radicals. Xanthine oxidase has been shown to be a major source of free radical generation under ischemic conditions ${ }^{5}$.

Xanthine oxidase (XO) is an enzyme that catalyzes the chain reactions of hypoxanthine oxidizing to xanthine and xanthine oxidizing to uric acid and hydrogen peroxide. Oxidation requires the addition of oxygen and water. This process is important because it explains how humans are able to metabolize purines ${ }^{6}$. Under ischemic conditions, there is depletion of ATP and subsequent loss of membrane $\mathrm{Ca}^{2+}$ gradient. Increased $\mathrm{Ca}^{2+}$ levels activate $\mathrm{Ca}^{2+}$ dependent proteases which are converted into xanthine oxidase ${ }^{7}$. Thus xanthine oxidase in ischemic conditions of the heart may play 
an important role in generating free radical mediated damage ${ }^{1}$.

Malondialdehyde (MDA) is a highly reactive three carbon dialdehyde produced as a byproduct of polyunsaturated fatty acid peroxidation and arachidonic acid metabolism. MDA readily combines with several functional groups on molecules including proteins, lipoproteins, and $\mathrm{DNA}^{8}$. Polyunsaturated fatty acid peroxides further react to form MDA. MDA can be found in most biological samples as a result of lipid peroxidation ${ }^{5}$.

In this study, the levels of xanthine oxidase and MDA were measured in MI patients and compared with healthy persons as control. Study protocols were approved by the AlShaab Teaching Hospital ethics committee.

\section{Materials and Methods}

$10 \mathrm{ml}$ venous blood specimens were collected in EDTA vacutainer from 100 patients with acute myocardial infarction who were attending the Sudanese Armed Forces Hospital, the Cardiac Centre of Ahmed Quasim Hospital, and Al-Shaab Teaching Hospital. Clinical examination of all patients was done to detect any co-existing disorder. Cases with known organic disorders were excluded from the study.

50 healthy volunteers -age and sex matchedserved as control group. Both healthy and patient groups comprised of non-smokers and within the age group of 40-65 years. Informed consent was taken from each patient and healthy person employed in the study.

Assay of Xanthine Oxidase Activity: ${ }^{9}$

Principle of the xanthine oxidase method:

Xanthine $+\mathrm{O}_{2}+\mathrm{H}_{2} \mathrm{O} \stackrel{\text { xanthine oxidase }}{\longrightarrow}$ Uric acid $+\mathrm{H}_{2} \mathrm{O}_{2}$

The rate of formation of uric acid is determined by measuring increased absorbance at $290 \mathrm{~nm}$.

A unit of activity is that forming one micromole of uric acid/minute.

\section{Reagents}

Solution $(\mathrm{A})=$ Tris- $\mathrm{HCl}$ buffer, $\mathrm{pH}$ 7.5: 0.1M

Solution (B) = Xanthine solution: $10 \mathrm{mM}$

Solution $(\mathrm{C})=$ Oxonic acid potassium salt solution: $1 \mathrm{mM}$

Solution (D) = Enzyme diluent: 50mM
The buffer mixture was prepared by adding $2.24 \mathrm{ml}$ from solution (A) to $0.08 \mathrm{ml}$ from solution (C) and $0.08 \mathrm{ml}$ from solution (D) in a test tube and was incubated at $37^{\circ} \mathrm{C}$ for about 5 minutes.

\section{Procedure:}

Into the test tube of the cuvettes $1.9 \mathrm{ml}$ of the buffer mixture above were added to $0.1 \mathrm{ml}$ of sample and $1.0 \mathrm{ml}$ of solution B while in the control tube $1.9 \mathrm{ml}$ of the buffer mixture, $0.1 \mathrm{ml}$ of sample and $1.0 \mathrm{ml}$ of distilled water were pipetted. The increase in optical density (OD) at $290 \mathrm{~nm}$ against water for three minutes in a spectrophotometer (Camspec. UV/VIS, UK) was recorded, and the OD per minute was calculated.

\section{Assay of malondialdehyde (MDA)} estimation:

The method is Thiobarbituric acid (TBA) based colorimetric. Assay is based on the reaction of MDA with TBA forming a MDA$\mathrm{TBA}_{2}$ adducts that absorbs strongly at $532 \mathrm{~nm}^{10}$.

In test tube mix the following: Plasma $(0.2$ $\mathrm{ml}), 8.1 \%$ sodium dodecyl sulphate $(0.8 \mathrm{ml})$, Glacial acetic acid $(0.5 \mathrm{ml})$ and $0.8 \%$ thiobarbituric acid $(1.5 \mathrm{ml})$.

Contents of the tubes were mixed and heated over water bath maintained at $90^{\circ} \mathrm{C}$ for one hour and immediately cooled thereafter under running water. Then in each test tube add 1.0 $\mathrm{ml}$ of distilled water and $5.0 \mathrm{ml}$ of n-butanol and pyridine $(15: 1 \mathrm{v} / \mathrm{v})$. Then contents of test tubes were mixed and centrifuged at 8000 $\mathrm{rpm}$ for ten minutes. The upper layer was aspirated out and color intensity was measured at $532 \mathrm{~nm}$ colorimetry (Roche Integra 700).

Statistical analysis were carried out using Student's ' $t$ ' test by statistical packages for social science software (SPSS).Values of $\mathrm{p}<0.05$ were considered statistically significant.

\section{Results}

As shown in table $1 \& 2$, specific activity of xanthine oxidase increases in the blood of patients with myocardial infarction when 
compared to healthy persons $(\mathrm{p}<0.05)$, malondialdehyde (MDA) levels are also statistically significantly increased in the blood of patients with myocardial infarction when compared to healthy controls $(\mathrm{p}<0.05)$. Table (1): Xanthine oxidase level in the blood of MI patient Compared to control group

\begin{tabular}{l|lll} 
Cases & $\mathrm{N}$ & $\begin{array}{l}\mathrm{XO}(\text { units } / \mathrm{mg} \\
\text { protein) }\end{array}$ & $\mathrm{p}$ \\
\hline $\begin{array}{l}\text { Patients } \\
\text { with MI }\end{array}$ & 100 & 0.0495 & $\mathrm{P}<0.05$ \\
$\begin{array}{l}\text { Healthy } \\
\text { persons }\end{array}$ & 50 & 0.0102 &
\end{tabular}

Table (2): MDA level in the blood of MI patient Compared to control group

\begin{tabular}{l|lll} 
Cases & $\mathrm{N}$ & $\begin{array}{l}\text { MDA } \\
\left(\text { nmole } \times 10^{6} /\right.\end{array}$ & $\mathrm{p}$ \\
$\mathrm{ml}$ blood $)$ & \\
\hline $\begin{array}{l}\text { Patients } \\
\text { with MI }\end{array}$ & 100 & 63.61 & $\mathrm{P}<0.05$ \\
$\begin{array}{l}\text { Healthy } \\
\text { persons }\end{array}$ & 50 & 29.35 &
\end{tabular}

Table 3 showed that the sensitivity of xanthine oxidase (XO) and malondialdehyde (MDA) was $100 \%$ and $88 \%$ respectively in patients with myocardial infarction (MI) and it was $0 \%$ in the control group for both tests.

Table (3): Sensitivity of XO and MDA tests in the MI patient group.

\begin{tabular}{l|clll} 
Cases & $\mathrm{N}$ & $\begin{array}{l}\text { No. of } \\
\text { XO } \\
\text { elevated } \\
\text { results }\end{array}$ & $\begin{array}{l}\text { No. of } \\
\text { MDA } \\
\text { elevated } \\
\text { results }\end{array}$ & p \\
\hline $\begin{array}{l}\text { MI } \\
\begin{array}{l}\text { Patients } \\
\text { Control } \\
\text { group }\end{array}\end{array}$ & 100 & $100 \%$ & $88 \%$ & \\
\hline
\end{tabular}

\section{Discussion}

Xanthine oxidase is an important source of free radical generation. Under ischemic conditions, increased $\mathrm{Ca}^{2+}$ levels activates $\mathrm{Ca}^{2+}$ dependent proteases which cause selective proteolysis of the dehydrogenase to convert it into xanthine oxidase which acts both on hypoxanthine and xanthine at the expense of molecular oxygen to produce superoxide ion ${ }^{10}$.

In this study we found significant increase $(p<0.05)$ in the activity of xanthine oxidase and the levels of MDA in the blood of patients with myocardial infarction compared to the control group indicating that myocardial ischemia has a definite correlation with xanthine oxidase activity and the levels of MDA and thus the measurement of xanthine oxidase activity may be used as a biochemical marker of myocardial infarction along with ECG. These findings were in agreement with those of Rashmi et al ${ }^{11}$.

As the marker of the ischemic myocardial syndrome, xanthine oxidase was shown to be better than MDA test. MDA in the blood of patients with myocardial may also be used but the sensitivity of MDA ( $88 \%$ ) was less than that of xanthine oxidase $(100 \%)$, also MDA showed increased levels in healthy persons $(2 \%)$ while XO tests showed no elevation in the control group (0\%). Moreover, the measurement of MDA levels is complicated and time consuming as compared to the assay of xanthine oxidase activity. Elsewhere XO and MDA tests were suggested to be the next generation of cardiac diseases markers ${ }^{12}$.

In a previous study at 2002 troponin was found to rise following strenuous exercise and in obese persons in the absence of heart disease $^{13}$. Pasquale et al ${ }^{14}$ also reported that $12.7 \%$ out of 102 patients with acute coronary syndromes were false negative for troponin results. It was reported that the troponin test reached a peak sensitivity of $96 \%$ and a specificity of $93 \%$ at 18 hours after symptom onset $^{15}$. Thus, in comparison to these previous studies, the test of xanthine oxidase may be proposed as a useful biochemical marker of myocardial infarction more than troponin.

\section{Acknowledgement}

Authors are thankful for head-department of Biochemistry laboratory, Khartoum University for allowing us to use the laboratory equipment during this study. 


\section{References}

1. Christenson RH, Azzazy HM. Biochemical markers of the acute coronary syndromes. Clin Chem 1998; 44: 1855-1864.

2. Roberts R. Enzymatic diagnosis of acute myocardial infarction. Chest 1988;93: 3S-6S..

3. Pandey NR, Kaur G, Chandra M, Sanwal GG, Misra MK. Enzymatic oxidant and antioxidants of human blood platelets in unstable angina and myocardial infarction. Int J Cardiol 2000; 76:33-8.

4. Heidenreich PA, Allogiamento T, Melsop K, McDonald KM, Alan SGo, Heatky MA. The prognostic valve of troponin in patients with non-ST elevation acute coronary syndromes: a meta analysis. J Am Coll Cardiol 2001;38: 478-85.

5. Gorman SLT, Zweier JL. Evaluation of the role of xanthine oxidase in myocardial reperfusion injury. J Biol Chem 1990; 265:6656-63.

6. Hille R. "Structure and Function of Xanthine Oxidoreductase". European Journal of Inorganic Chemistry 2006 (10): 1905-2095..

7. Chambers DE, Parks DA, Patterson G, Roy R, McCord JM, Yoshida S, Parmley LF, Downey JM. Xanthine oxidase as a source of free radical damage in myocardial ischemia. J Mol Cell Cardiol 1985; 17: 145-52

8. Wu AH. Analytical and clinical evaluation of new diagnostic tests for myocardial damage. Clin Chem Acta 1998;272: 11-21.
9. Nishino, T. The conversion of xanthine dehydrogenase to xanthine oxidase and theroleoftheenzyme in reperfusion injury.J. Biochem. (1994)1 16, 1-6.

10. Chaudhary, A.K., Nokubo, M., Reddy, G.R., Yeola, S.N., Morrow, J.D., Blair, I.A. \& Marnett, L.H.

Detection of endogenous malondialdehydedeoxyguanosine adducts in human liver. Science, (1994)265, 1580-1584.

11. Rashmi Raghuvanshi, Aiki Kaul, Pushpa Bhakuni, Aparna Mishra and M.K. Misra. Xanthine oxidase as a marker of myocardial infarction. Indian Journal of Clinical Biochemistry, 2007 / 22 (2) 90-92

12. Dawson J, Walters M. Uric acid and xanthine oxidase: future therapeutic targets in the prevention of cardiovascular disease. British journal of clinical pharmacology October 2006)62: 633.

13. Hamm CW, Giannitsis E, Katus HA. Cardiac troponin elevations in patients without acute coronary syndrome. Circulation 2002;106:2871-2.

14. Pasquale DP, Cannizzaro S, Scalzo S, Maringhini G, Sarullo FM, Cacia A, Paterna S. Sensitivity, specificity and predictive value of the echocardiography and troponin-T test combination in patients with non-ST elevation acute coronary syndromes. Int J Cardiovasc Imaging. 2004 Feb;20(1):37-46.

15. Peter A. Kavsak, and Matthew J. McQueen. High sensitivity cardiac troponin testing. CMAJ. November 9, 2010; 182 (16). 